\title{
Safety assessment of bio-synthesized iodine-doped silver nanoparticle wound ointment in experimental rats
}

\author{
Oluwatosin Kudirat Shittu ${ }^{1,2,3}$, Olawale Issac Oluyomi ${ }^{1,2}$ and Theresa Yebo Gara ${ }^{1 *}$ (D)
}

\begin{abstract}
Background: In the wake of antibiotic resistance, treatment of intractable wound have been very challenging and any alternative treatment which may lead to less use of antibiotics deserves further exploitation. Nanoparticle conjugates has potentially not only reduce antibiotic use but it has been considered safe and effectively disinfect wounds already colonized with resistant bacteria as well as promoting granulation tissue formation. In this study, lodine-doped silver nanoparticle Ointment (Ag-I NPs) was investigated for its toxicological effect on excisional wound of albino rats.

Methods: Aqueous extraction of Piper guineense leaf was carried out and used for the synthesis of Ag-l NPs. The synthesized Ag-I NPs were characterized by Ultraviolet visible spectrophotometer which confirmed the availability of silver nanoparticles. The particles were then used to prepare a wound healing ointment for treating excision wound inflicted on wistar rat model. Blood samples, liver and kidney biopsies were collected on the 21st day of the experiment from all the rats for hematology, biochemical and histopathological analysis.
\end{abstract}

Result: In the hematological and biochemical analysis, hemoglobin ( $\mathrm{Hb})$, packed cell volume (PCV) and mean corpuscular hemoglobin (MCH), superoxide dismutase (SOD), alkaline phosphatase (ALP) of experimental rats treated with Ag-I NPs were significantly different $(p<0.05)$ compared to the untreated group. In the histopathology, the photomicrograph of the liver showed the normal control, PEG, Ag-NP, and Ag-I NP groups remained intact displaying distinctive histo-morphological appearance and stable cell density while the untreated (UTD) group showed fatty liver and reduced cellular density. The kidney photomicrograph of the normal control and Ag- I NP groups were present with intact renal corpuscles while the other photomicrographs displayed corpuscular degeneration marked by the large halo-spaced bowman space.

Conclusion: Silver nanoparticles (Ag NPs) and iodine-doped silver nanoparticle (Ag-I NP) altered haematological parameters in the rats and also influenced some biochemical changes in the serum of the rats. While in the histopathological study, the antioxidant present in the plant extract used to synthesize Ag NPs and Ag I-NPs may have functioned in synergy to maintain and preserve the integrity of the hepatocytes and renal corpuscles of the rats.

Keywords: lodine-doped silver nanoparticles, Excision wound, Healing, Antioxidant

\footnotetext{
* Correspondence: t.gara@futminna.edu.ng

${ }^{1}$ Biochemistry Department, School of Life Sciences, Federal University of

Technology, P.M.B 65, Minna, Niger State, Nigeria

Full list of author information is available at the end of the article
}

\section{Springer Open}

(c) The Author(s). 2021 Open Access This article is licensed under a Creative Commons Attribution 4.0 International License, which permits use, sharing, adaptation, distribution and reproduction in any medium or format, as long as you give appropriate credit to the original author(s) and the source, provide a link to the Creative Commons licence, and indicate if changes were made. The images or other third party material in this article are included in the article's Creative Commons licence, unless indicated otherwise in a credit line to the material. If material is not included in the article's Creative Commons licence and your intended use is not permitted by statutory regulation or exceeds the permitted use, you will need to obtain permission directly from the copyright holder. To view a copy of this licence, visit http://creativecommons.org/licenses/by/4.0/. 


\section{Introduction}

Wounds are an inevitable occurrence that arises during one's lifetime. They are triggered by microbial infection, physical or chemical accident. Occasionally, wounds may emerge as severe or chronic. Chronic wounds are often accompanied with the failure of a patient to heal effectively and ascertain the origin or trigger of the attrition as normally seen in diabetes [1-3].

Wound care is an increasingly important worldwide issue owing to the rising rate of metabolic diseases and their susceptibility to microscopic infections which increases public health issues and creating a huge medical, economic, social and psychological strain especially in third world nations [4-6]. With an approximately 7.3 billion population globally, nearly 1 billion individuals are likely to experience acute and/or chronic wound in which poverty, bad sanitation, malnutrition and poisoning may possibly trigger or exacerbate their effects [7]. Wound healing is a complicated predefined cascade of well-orchestrated histology occurrences that evolves in alternating stages, (hemostasis, inflammation, cell proliferation/granulation and remodeling/maturation) revealed through a sequence of molecular, biochemical and behavioral phenomena, generally contributing to anatomical tissue reconstitution $[8,9]$.

Iodine a dark non-metallic crystalline solid is probably the best known antiseptic and has been used for more than a century [10]. Iodine nanoparticles have been reported to be synthesized chemically using calcium lactate, disodium hydrogen phosphate, polyvinyl pyrolidone and iodine solution as precursor [11]. The use of plants for nanoparticle synthesis has advantages over chemical and other biological processes because it is cheap, non-toxic, eliminates the process of maintaining cell cultures and is suitable for large-scale nanoparticle synthesis [12].

$P$. guineense belongs to the plant family Piperaceae. It is a well-known good reducing agent utilized in gold nanoparticles synthesis [13]. It has been reported to possess antioxidant properties, aids in uterine contractions and antimicrobial activities $[14,15]$. The seed and leaf of $P$. guineense have also been reported to contain flavonoids, cardiac glycosides, alkaloid, terpenes and tannins [16]. In this study, the aqueous leaf extract of $P$. guineense was used as a bio-reducing agent in the biosynthesis of iodinedoped silver nanoparticle wound ointment and its safety was investigated in experimental rats.

\section{Materials and methods}

\section{Plant preparation}

Fresh leaves of P. guineense were collected from Oboloafor village in Enugu State, Nigeria. The plant was identified at in the Department of Plant Biology, Federal University of Technology Minna, Nigeria. The voucher number is FUT/PLB/Pip/025. The leaves were washed with distilled water and air dried at room temperature for 15 days to prevent the destruction of thermo labile constituents of the plant by direct sun rays. The dried leaves were pulverized into coarse powder, after which 5 $\mathrm{g}$ of the plant sample ( $P$. guineense leaves) was weighed, add to $100 \mathrm{ml}$ of sterile deionized water in conical flask, boiled for $5 \mathrm{~min}$ and filtered using a whatmann filter paper [13].

\section{Biosynthesis of iodine-doped silver nanoparticle}

Aqueous extract of $P$. guineense $(10 \mathrm{ml})$ was added to 90 $\mathrm{ml}$ of aqueous solution of $1 \mathrm{mM} \mathrm{AgNO}$ and heated with stirrer at $70{ }^{\circ} \mathrm{C}$ for $60 \mathrm{~min}$ at $\mathrm{pH}$. Then $50 \mathrm{ml}$ of a 0.1 $\mathrm{mM} \mathrm{I}_{2}$ aqueous solution was slowly dropped under magnetic stirring in 30-60 min and the solution was kept stirring continuously for $1 \mathrm{~h}$ to assure further reaction. Colour change was observed and the iodine-doped silver nanoparticle was collected and monitored with a UV-vis spectrophotometer (UV-1800 shimadzu) at the wavelength of 200-900 nm using a quartz cuvette [13].

\section{Preparation of wound healing ointment using Ag-I NPs}

The ointment was prepared by dissolving $10 \mathrm{~g}$ of Polyethylene glycol (PEG) $3000 \mathrm{Mw}$ in $30 \mathrm{ml}$ of synthesized iodine-doped silver nanoparticles (Ag-I NPs) to stabilize it [17]. The mixture was poured into a plastic jars and stored in a cool dry place.

\section{Experimental animals}

Male and female albino wistar rats weighing between $176 \pm 37.48 \mathrm{~g}$ were obtained from Niger State Polytechnic, Zungeru, Niger state. They were kept in cages at the School of life science's animal housing unit, Federal University of Technology, Minna and allowed to acclimatize for 21 days with free access to feed and water ad-libitum.

\section{Experimental design}

The rats (24) were weighed and randomly assigned into six groups of four rats each. All rats were inflicted with wound except the normal control group.

\section{Group 1: Normal control group}

Group 2: treated with povidone iodine (standard drug)

Group 3: untreated group (Negative control)

Group 4: treated with poly ethylene glycol (PEG) alone

Group 5: treated with PEG + silver nanoparticles (Ag

NPs)

Group 6: treated with PEG + iodine-doped silver nanoparticles (Ag-I NPs

\section{Serum and liver collection}

The method described by Yakubu et al., [18] was employed in the serum and liver collection. 
Formaldehyde was used to preserve harvested animal organs (liver and kidney) for histopathological examination.

\section{Haematological studies}

Automated hematologic analyzer (D\&H 600 model), was used to determine Haemoglobin $(\mathrm{Hb})$ count, packed cell volume (PCV), mean cell volume (MCV), Mean corpuscular haemoglobin $(\mathrm{MCH})$, Mean corpuscular haemoglobin concentration (MCHC), red blood cells (RBC), platelet count $\left(\mathrm{PLCx} 10^{2}\right)$, total white blood cells (TWBC), neutrophils, lymphocytes, monocytes, eosinophils, basophils and red cell distribution width (RDWC) by method described by Dacie and Lewis [19].

\section{Biochemical analysis}

\section{Superoxide dismutase activity assay}

Superoxide dismutase (SOD) activity was determined based on the ability of SOD to inhibit the auto-oxidation of epinephrine to adrenochrome at alkaline $\mathrm{pH}$ [20]. $25 \mu \mathrm{l}$ of the supernatant obtained from the centrifuged liver homogenate was added to a mixture of $0.1 \mathrm{mM}$ adrenaline in carbonate buffer (10.2) in a total volume of $1 \mathrm{ml}$ and the formation of adrenochrome was measured at $295 \mathrm{~nm}$.

\section{Catalase activity assay}

Catalase (CAT) was estimated by the method of Sinha et al., [21]. The reaction mixture $1.5 \mathrm{ml}$ contained $1.0 \mathrm{ml}$ of $0.01 \mathrm{M}$ phosphate buffer (pH7.0) $0.1 \mathrm{ml}$ of tissue homogenate and $0.4 \mathrm{ml}$ of $2 \mathrm{M} \mathrm{H}_{2} \mathrm{O}_{2}$. The reaction was stopped by the addition of $2.0 \mathrm{ml}$ dichromate-acetic acid reagent ( $5 \%$ potassium dichromate and glacial acetic acid were mixed in 1:3 ratio). Then the absorbance was measured at $530 \mathrm{~nm}$.

\section{Estimation of glutathione peroxidase (GPx)}

Glutathione peroxidase (GPx) was measured by the method described by Rotruck et al., [22] Briefly, the reaction mixture contained $0.2 \mathrm{ml} 0.4 \mathrm{M}$ phosphate buffer (pH7.0), $0.1 \mathrm{ml} 10 \mathrm{mM}$ sodium azide, $0.2 \mathrm{ml}$ tissue homogenized in $0.4 \mathrm{M}$ phosphate buffer pH7.0. $0.2 \mathrm{ml}$ tissue homogenized in $0.4 \mathrm{M}$, phosphate buffer, $\mathrm{pH} 7.0$, $0.2 \mathrm{ml}$ reduced glutathione, $0.1 \mathrm{ml} 0.2 \mathrm{mM}$ hydrogen peroxide. The contents were incubated for $10 \mathrm{~min}$ at $37^{\circ} \mathrm{C}$, $0.4 \mathrm{ml} 10 \%$ TCA was added to stop the reaction and centrifuged at $3200 \times \mathrm{g}$ for $20 \mathrm{~min}$. The supernatant was assayed for glutathione content using Ellman's reagent (19.8 mg 5,5'-dithiobisnitrobenzoic acid [DTNB] in 100 $\mathrm{ml} 0.1 \%$ sodium nitrate).

\section{Assay of alkaline phosphatase (ALP)}

The method described by Bassey et al. [23] as modified by Wright et al. [24] using Randox kits. In a cuvette,
$10 \mu \mathrm{l}$ of sample was mixed with $500 \mu \mathrm{l}$ of the reagent. The initial absorbance was read at $405 \mathrm{~nm}$, and subsequently over $3 \mathrm{~min}$. The mean absorbance per minute was used in the calculation: ALP activity $(\mathrm{IU} / \mathrm{l})=$ $2742 \times \Delta \mathrm{A} 405 \mathrm{~nm} / \mathrm{min}$; Where: $2742=$ Extinction coefficient; $\Delta \mathrm{A} 405 \mathrm{~nm} / \mathrm{min}=$ change in absorbance per minute for the homogenate sample.

\section{Assay of alanine transaminase (ALT) activity}

The method described by IFCC [25] using Randox kits was used. $50 \mu \mathrm{l}$ of the sample and $500 \mu \mathrm{l}$ of the ALT reagent were mixed in a test tube, and the initial absorbance at $340 \mathrm{~nm}$ was read after $1 \mathrm{~min}$. The timer was started simultaneously and further readings of the absorbance were taken after 1,2 , and $3 \mathrm{~min}$. ALT activity $(\mathrm{nm} / \mathrm{min})=1746 \times \Delta \mathrm{A} \quad 340 \mathrm{~nm} / \mathrm{min}, \Delta \mathrm{A} \quad 340 \mathrm{~nm} / \mathrm{min}=$ change in absorbance per minute for the homogenate sample, 1746 = Extinction coefficient.

\section{Assay of aspartate transaminase (AST) activity}

The method described by IFCC [25] using Randox kits was used. $50 \mu \mathrm{l}$ of the sample and $500 \mu \mathrm{l}$ of the AST reagent were mixed in a test tube, and the initial absorbance at $340 \mathrm{~nm}$ was read after $1 \mathrm{~min}$. The timer was started simultaneously and further readings of the absorbance were taken after 1, 2, and $3 \mathrm{~min}$. AST activity $(\mathrm{nm} / \mathrm{min})=1746 \times \Delta \mathrm{A} \quad 340 \mathrm{~nm} / \mathrm{min} ; \Delta \mathrm{A} \quad 340 \mathrm{~nm} / \mathrm{min}=$ change in absorbance per minute for the homogenate sample; 1746 = Extinction coefficient.

\section{Total protein}

Total protein concentration was determined according to the method of Lowry et al. [26].

In an alkaline medium, protein reacts with the copper in the Biuret reagent leading to an increase in absorbance due to formation of colored complex. Reagent (2.5 $\mathrm{ml}$ ) and $0.05 \mathrm{ml}$ serum sample were mixed. It was then incubated at room temperature for $10 \mathrm{~min}$. The absorbance was read at $540 \mathrm{~nm}$ against reagent blank.

\section{Statistical analysis}

The analysis was performed using the SPSS statistical package for WINDOWS (version 21.0; SPSS Inc., Chicago). Results were subjected to analysis of variance (ANOVA) to determine their level of significance. Data were expressed as the mean \pm standard error of mean. Values were considered statistically significant at $p<0.05$ and non-significant at $p<0.05$ difference.

\section{Result and discussion Haematological studies}

Examination of the volumes and structure of the blood cells serves a crucial role in the physiological and pathological condition of an animal [27]. The impact of 21 
days treatment of excision wound with polyethylene glycol (PEG), silver nanoparticles (Ag NP) and iodinedoped silver nanoparticle (Ag-I NP) in haematological parameters of experimental animals is displayed on Table 1. The outcome indicates that TWBC decreases considerably $(P<0.05)$ in experimental animals treated with Ag-I NPs while lymphocyte, neutrophil, red blood cells $(\mathrm{RBC})$, mean cell volume (MCV) and platelet count did not show any significant distinction $(P>0.05)$. Treatment with Ag-I NPs also produced significant decrease $(P<0.05)$ in $\mathrm{Hb}, \mathrm{PCV}, \mathrm{MCH}$ and $\mathrm{MCHC}$, while the monocytes, eosinophils, basophils and red cell distribution width $($ RDWC) were significantly $(P<0.05)$ elevated. It is worthy of note in this research that wound surface application of Ag-I NPs can substantially change the normal range of hematological parameters either negatively or positively. Granulocytes are parts of the immune system that fight multicellular parasites, certain vertebrate diseases, influence allergy and respiratory related complications. Significant rise $(P<0.05)$ in eosinophil, monocyte and basophil improves the animal's capacity to produce antibodies by phagocytosis, have a large degree of infection resistance and improved adaptability to local circumstances of the environment and disease [28].

Mean cell volume (MCV), haematocrit and haemoglobin are reported to be major indicators for the assessment of erythrocytes, anemia detection and red blood cell $(\mathrm{RBC})$ production in the bone marrow of mammals $[29,30]$. The non-significant impact of Ag-I NPs on the RBC maybe a sign of erythropoiesis or depressed RBC production and it also indicates that Ag-I NPs could have the ability to prevent the discharge of erythropoietin in the kidney, which is RBC production's humoral regulator [31]. The significant impact of Ag-I NPs on hematocrit, $\mathrm{MCH}$ and haemoglobin, may suggest that the blood oxygen-carrying potential and the quantity of oxygen supplied to the tissues after the administration of Ag-I NPs was altered as hematocrit and haemoglobin are very essential in the transfer of respiratory substances [32]. The observed decrease in MCHC maybe sign of swollen erythrocytes which indicate that $P$. guineense extract is likely poisonous to $\mathrm{MCHC}$ and other RBC lineage. The platelets in the rats treated with Ag-I NPs were similar with the control and did not trigger any adverse effects on the blood component platelets population.

Reactive oxygen species are known to mediate cellular damage. Anti-oxidants enzymes such as superoxide dismutase (SOD), glutathione peroxidase (GPx), and catalase play crucial roles in removing reactive oxygen species (ROS) released during metabolic processes [33, 34]. NADPH oxidase $\left(\mathrm{NOX}_{2}\right)$ is produced at elevated concentrations in inflammatory cell plasma membranes and enabled during phagocytosis, resulting in large amounts of superoxide radical anions being produced which attack invasive pathogens, ultimately destroying them to help with phagocytosis [35, 36]. However, when superoxide is secreted in high amount, it affects the neighboring tissues and it is either dis-mutated by superoxide dismutase (SOD) or a spontaneous reaction to $\mathrm{O}_{2}$ and $\mathrm{H}_{2} \mathrm{O}_{2}$. The $\mathrm{H}_{2} \mathrm{O}_{2}$ is further converted into water by catalase or by glutathione peroxidase (GPx). In this study, the activities of SOD were considerably greater $(p<0.05)$ after 21 days of Ag NP and Ag-I NPs wound surface treatment when compared to the control group.

Table 1 Effects of 21-days treatment of wound with PEG, Ag-NPs and Ag-INPs on haematological parameters of albino rats

\begin{tabular}{|c|c|c|c|c|c|c|}
\hline Parameters & Control & Standard & Untreated & PEG & Ag NP & Ag-I NP \\
\hline $\mathrm{Hb}(\mathrm{g} / \mathrm{L})$ & $10.95 \pm 1.35^{b c}$ & $9.50 \pm 0.00^{b}$ & $11.75 \pm 1.05^{b c}$ & $13.35 \pm 0.05^{c}$ & $13.50 \pm 0.60^{c}$ & $4.95 \pm 0.55^{a}$ \\
\hline PCV (\%) & $35.00 \pm 3.00^{b c}$ & $30.00 \pm 0.00^{b}$ & $37.00 \pm 3.00^{b c}$ & $42.00 \pm 2.00^{c}$ & $41.50 \pm 1.50^{c}$ & $14.50 \pm 1.50^{\mathrm{a}}$ \\
\hline MCV (fL) & $56.00 \pm 2.00^{\mathrm{a}}$ & $54.00 \pm 1.00^{\mathrm{a}}$ & $56.00 \pm 2.00^{\mathrm{a}}$ & $54.50 \pm 2.50^{\mathrm{a}}$ & $51.00 \pm 0.00^{a}$ & $54.00 \pm 0.00^{\mathrm{a}}$ \\
\hline $\mathrm{MCH}(\mathrm{Pg})$ & $15.50 \pm 0.50^{b}$ & $17.00 \pm 1.00^{b}$ & $16.00 \pm 0.00^{b}$ & $17.00 \pm 0.00^{b}$ & $13.00 \pm 3.00^{\mathrm{ab}}$ & $8.00 \pm 2.00^{a}$ \\
\hline $\mathrm{MCHC}(\mathrm{g} / \mathrm{dL})$ & $28.00 \pm 2.00^{b}$ & $31.00 \pm 1.00^{b}$ & $30.00 \pm 0.00^{b}$ & $31.50 \pm 1.50^{b}$ & $26.00 \pm 6.00_{b}$ & $13.50 \pm 3.50^{\mathrm{a}}$ \\
\hline $\mathrm{RBC}\left(\times 10^{12} / \mathrm{L}\right)$ & $7.25 \pm 1.25^{\mathrm{ab}}$ & $5.60 \pm 0.30^{\mathrm{a}}$ & $7.35 \pm 0.55^{\mathrm{ab}}$ & $7.75 \pm 0.05^{\mathrm{ab}}$ & $11.05 \pm 1.95^{\mathrm{b}}$ & $7.15 \pm 2.45^{\mathrm{ab}}$ \\
\hline $\operatorname{PLC}\left(\times 10^{9} / \mathrm{L}\right)$ & $6.98 \pm 0.00^{\mathrm{a}}$ & $5.35 \pm 0.00^{\mathrm{a}}$ & $7.23 \pm 0.00^{a}$ & $8.23 \pm 6.50^{\mathrm{a}}$ & $7.64 \pm 3.40^{\mathrm{a}}$ & $1.27 \pm 9.28^{a}$ \\
\hline $\operatorname{TWBC}\left(\times 10^{9} / \mathrm{L}\right)$ & $3.10 \pm 0.00^{\mathrm{ab}}$ & $5.25 \pm 0.25^{b c}$ & $5.10 \pm 1.10^{b c}$ & $5.60 \pm 0.60^{c}$ & $10.20 \pm 0.90^{d}$ & $2.65 \pm 0.55^{a}$ \\
\hline Neu (\%) & $9.00 \pm 1.00^{\mathrm{a}}$ & $8.50 \pm 0.50^{\mathrm{a}}$ & $7.50 \pm 0.50^{a}$ & $10.50 \pm 0.50^{a}$ & $10.50 \pm 3.50^{a}$ & $17.50 \pm 12.50^{\mathrm{a}}$ \\
\hline Lym (\%) & $75.00 \pm 1.00^{\mathrm{a}}$ & $72.00 \pm 3.00^{\mathrm{a}}$ & $70.50 \pm 2.50^{\mathrm{a}}$ & $75.50 \pm 4.50^{\mathrm{a}}$ & $80.50 \pm 3.50^{\mathrm{a}}$ & $52.00 \pm 18.00^{\mathrm{a}}$ \\
\hline MEB (\%) & $16.00 \pm 2.00^{\mathrm{ab}}$ & $19.50 \pm 3.50^{\mathrm{ab}}$ & $22.00 \pm 2.00^{\mathrm{ab}}$ & $14.00 \pm 4.00^{\mathrm{a}}$ & $9.00 \pm 7.00^{\mathrm{a}}$ & $30.50 \pm 5.50^{b}$ \\
\hline RDWC (\%) & $15.30 \pm 0.40^{\mathrm{a}}$ & $15.85 \pm 0.55^{\mathrm{a}}$ & $16.15 \pm 0.25^{\mathrm{ab}}$ & $15.55 \pm 0.85^{\mathrm{a}}$ & $18.90 \pm 0.60^{c}$ & $18.75 \pm 1.35^{b c}$ \\
\hline
\end{tabular}

Biochemical analysis Values are expressed in mean \pm standard error of mean. Values with the same superscript across the row have no significant different at $p<0.05$

$\mathrm{Hb}$ Haemoglobin count, $P C V$ packed cell volume, $M C V$ mean cell volume, $M C H$ Mean corpuscular haemoglobin, $M C H C$ Mean corpuscular haemoglobin concentration, $R B C$ red blood cells, $P L C \times 10^{2}$ platelet count, TWBC total white blood cells, Neu neutrophils, Lym lymphocytes, MEB monocytes, eosinophils, basophils and $R D W C$ red cell distribution width 
Table 2 Effects of 21 days treatment of wound with PEG, Ag-np and Ag-INP on antioxidant enzymes of albino rats

\begin{tabular}{lllllll}
\hline Enzymes & Control & Standard & Untreated & PEG & Ag NP & Ag-I NP \\
\hline SOD U/mL & $1.06 \pm 0.13^{\mathrm{a}}$ & $2.26 \pm 0.26^{\mathrm{bc}}$ & $2.53 \pm 0.13^{\mathrm{c}}$ & $1.86 \pm 0.35^{\mathrm{b}}$ & $4.00 \pm 0.00^{\mathrm{d}}$ & $2.00 \pm 0.00^{\mathrm{bc}}$ \\
GPx $\mu \mathrm{g} / \mathrm{mL}$ & $1.07 \pm 0.22^{\mathrm{a}}$ & $0.81 \pm 0.11^{\mathrm{a}}$ & $1.12 \pm 0.12^{\mathrm{a}}$ & $1.07 \pm 0.19^{\mathrm{a}}$ & $1.86 \pm 0.02^{\mathrm{b}}$ & $1.14 \pm 0.28^{\mathrm{a}}$ \\
CAT U/mL & $0.65 \pm 0.03^{\mathrm{b}}$ & $0.70 \pm 0.01^{\mathrm{b}}$ & $0.69 \pm 0.05^{\mathrm{b}}$ & $0.65 \pm 0.04^{\mathrm{ab}}$ & $0.55 \pm 0.01^{\mathrm{a}}$ & $0.62 \pm 0.01^{\mathrm{ab}}$ \\
\hline
\end{tabular}

Values are expressed in mean \pm standard error of mean. Values with the same superscript across the row have no significant different at $p<0.05$. SOD Superoxide dismutase, GPX glutathione peroxidase and CAT catalase

The comparison of the anti-oxidants enzymes is shown in Table 2. This suggests that Ag NPs improved the secretion of SOD and prevented the harmful effects of superoxide radicals generated in the rats. Antioxidant properties contained in natural or synthetic products are known to have potentials to reduce the harmful effects caused by oxidative stress [37].

The activity of GPx in Ag NPs group was significantly increased compared with control group. While CAT activity, revealed a non-significant distinction after treatment with Ag NPs and Ag-I NPs. The increase in GPx activity may have occurred in response to boost immunity of the animals or a complementary mechanism to support the elimination of free radicals from the system [38]. Ag NPs may have enhanced GPx to suppressed oxidative stress in-vivo by maintaining hydrogen peroxide at a low level and modulating mechanisms involved in wound healing process such as blood clotting, thrombosis, angiogenesis, migration and fibrosis [39].

The assessment of serum biochemical indicators in experimental animals has become an invaluable technique for evaluating the clinical signs and functionality of organs as well as pathology and overall wellness status [40]. Alkaline phosphatase is frequently used to evaluate plasma membrane and endoplasmic reticulum integrity. The rise $(p<0.05)$ in ALP activity after 21 days of Ag NP and Ag-I NPs wound repair proposed that the functionality and structure of the endoplasmic reticulum and plasma membrane were compromised [41]. It also indicated that the nanoparticles prevented or stimulated the enzyme operations [42].

Aspartate transaminase (AST) and alanine transaminase (ALT) are hepatic tissue biomarkers that catalyze transamination reaction and used to evaluate the extent of hepatocellular damage. But the ALT activities provide more useful data relevant to hepatocyte integrity than the AST [43-45]. In this research, serum AST activities were significantly $(p<0.05)$ reduced while the levels of ALT were not significantly altered by Ag NP and Ag-I NP treatment relative to the control groups after 21 days treatment (Table 3). Similarly, AST activities reduced significantly in rats serum treated with colloidal AgNPs for 7 and 14 days [46]. The alterations observed in the levels of AST may have been initiated by the ability of AgNPs and Ag-INPs to disrupt the activities of the transaminase enzymes required for their optimal operations [47, 48]. Ag NP and Ag-I NP may have influenced transaminases selectively as there was no alteration of ALT operations in the animal serum.

Total proteins are valuable indicator of secretory, synthetic and excretory function of the liver [49]. The total protein (TP) were significantly reduced in rats administered Ag NP and Ag-I NP relative to control groups after 21 days. However, such reduced actions of TP may adversely impact the amino acid and carbohydrate breakdown with consequent declining effects on the production of ATP [40].

\section{Histopathological studies}

The liver photomicrograph on Fig. 1 displays the hepatocyte histomorphology (black arrows) and histoarchitectural cells of the experimental animals. This is to investigate the effect of surface application of Ag-NP, and Ag-I NP on the liver of experimental animals. Control (N), PEG, Ag-NP, and Ag-I NP display a distinctive histomorphological appearance with normal staining intensity and stable cell density and assortment. The central vein is represented by the black circles/CV. The

Table 3 Effects of 21-days treatment of wound with PEG, Ag NP and Ag-I NP on liver function enzymes of albino rats

\begin{tabular}{lllllll}
\hline E & Control & Standard & Untreated & PEG & Ag NP & Ag-I NP \\
\hline TP $(\mathrm{g} / \mathrm{dl})$ & $79.17 \pm 1.27^{\mathrm{c}}$ & $81.70 \pm 3.96^{\mathrm{c}}$ & $81.70 \pm 5.48^{\mathrm{c}}$ & $84.23 \pm 3.85^{\mathrm{c}}$ & $52.57 \pm 0.63^{\mathrm{a}}$ & $67.87 \pm 0.53^{\mathrm{b}}$ \\
AST $(\mathrm{U} / \mathrm{L})$ & $24.50 \pm 0.00^{\mathrm{cd}}$ & $23.33 \pm 1.16^{\mathrm{cd}}$ & $25.83 \pm 2.42^{\mathrm{d}}$ & $11.67 \pm 1.17^{\mathrm{a}}$ & $17.50 \pm 0.00^{\mathrm{b}}$ & $21.00 \pm 0.00^{\mathrm{bc}}$ \\
ALT(U/L) & $8.15 \pm 0.63^{\mathrm{a}}$ & $8.15 \pm 0.63^{\mathrm{a}}$ & $6.69 \pm 2.71^{\mathrm{a}}$ & $7.52 \pm 1.09^{\mathrm{a}}$ & $8.15 \pm 0.63^{\mathrm{a}}$ & $8.77 \pm 1.25^{\mathrm{a}}$ \\
ALP $(\mathrm{U} / \mathrm{L})$ & $294.40 \pm 46.00^{\mathrm{ab}}$ & $294.40 \pm 24.34^{\mathrm{ab}}$ & $294.40 \pm 40.10^{\mathrm{ab}}$ & $220.80 \pm 27.60^{\mathrm{a}}$ & $340.40 \pm 18.40^{\mathrm{b}}$ & $340.40 \pm 9.20^{\mathrm{b}}$ \\
\hline
\end{tabular}

Values are expressed in mean \pm standard error of mean. Values with the same superscript across the row have no significant different at $p<0.05$. $E$ Enzymes, $T P$ total protein, AST aspartate transaminase, ALT alanine transaminase and ALP alkaline phosphatase 


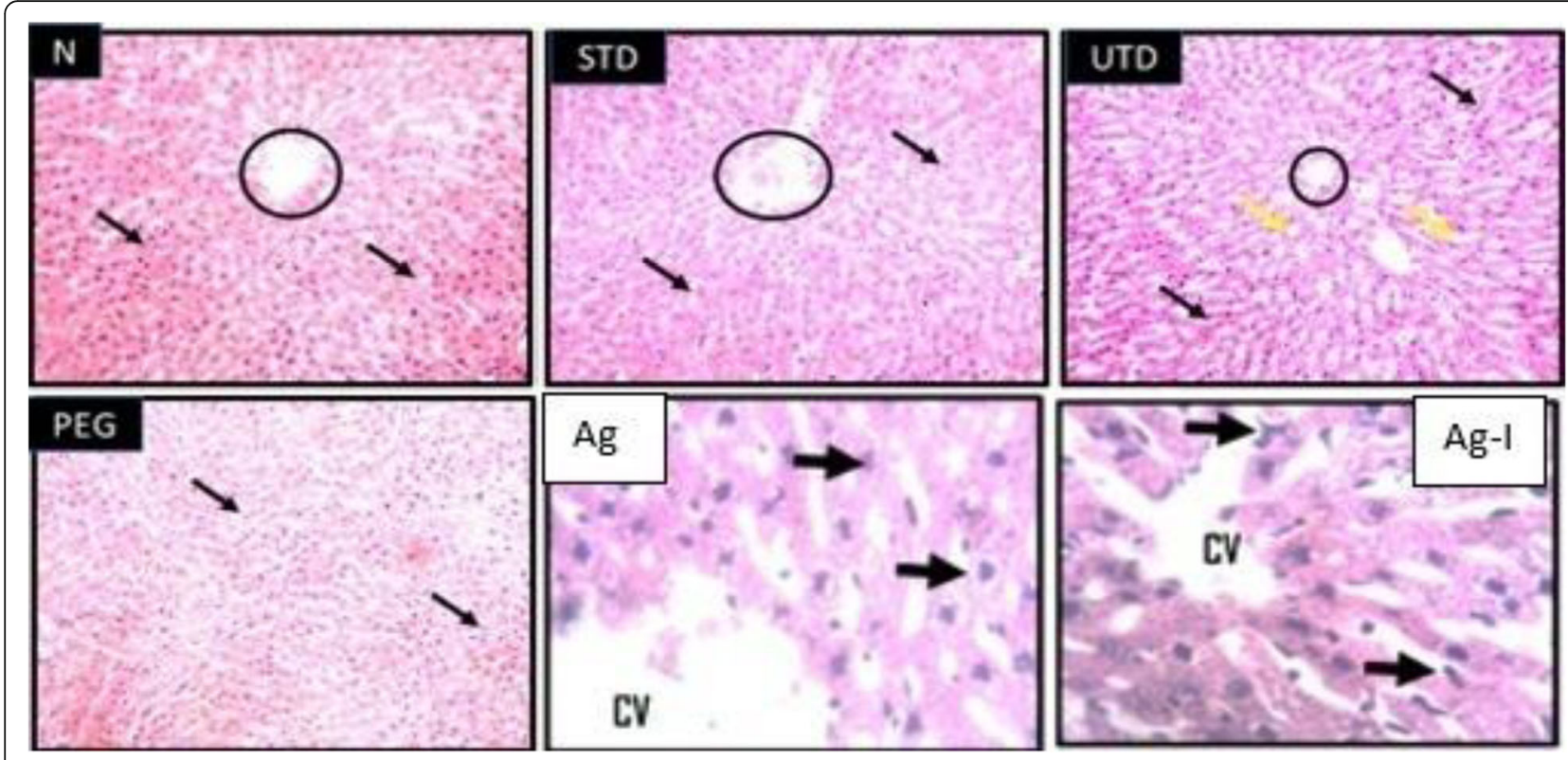

Fig. 1 Effect of PEG, Ag-NP, and Ag-I NP treatment on histological sections of liver in excision wound inflicted albino rats. Hematoxylin and eosin stain at $\times 100$ and $\times 400$ magnification

STD (povidone iodine) shows a typical histomorphology of the liver by the central vein, it appears clogged suggesting signs of cholestasis. Untreated (UTD) shows a fatty liver as indicated by the halospaced tiny fat droplets (yellow arrow) and reduced cellular density while the hepatocytes of Ag-NP, and Ag-I NP treated group remain intact. This implies that the biosynthesized Ag-NP, and Ag-I NP may have not induced any toxic injury on the liver. This result is consistent with the study of Umbreit et al. [50] which reported that murine models revealed no evidence of tissue disruption in response to nanoparticle treatment.

The kidney photomicrograph of experimental animals showing the renal cortex, component kidney corpuscles (black circle) and neighboring halo-spaced convoluted tubules (black arrows) shown in Fig. 2. The control group $(\mathrm{N})$ and Ag- I NP are present with intact renal corpuscles. Zhang et al. [51] reported that titanium dioxide nanoparticle has no effect on the renal cells. The rest of the photomicrographs presented with corpuscular

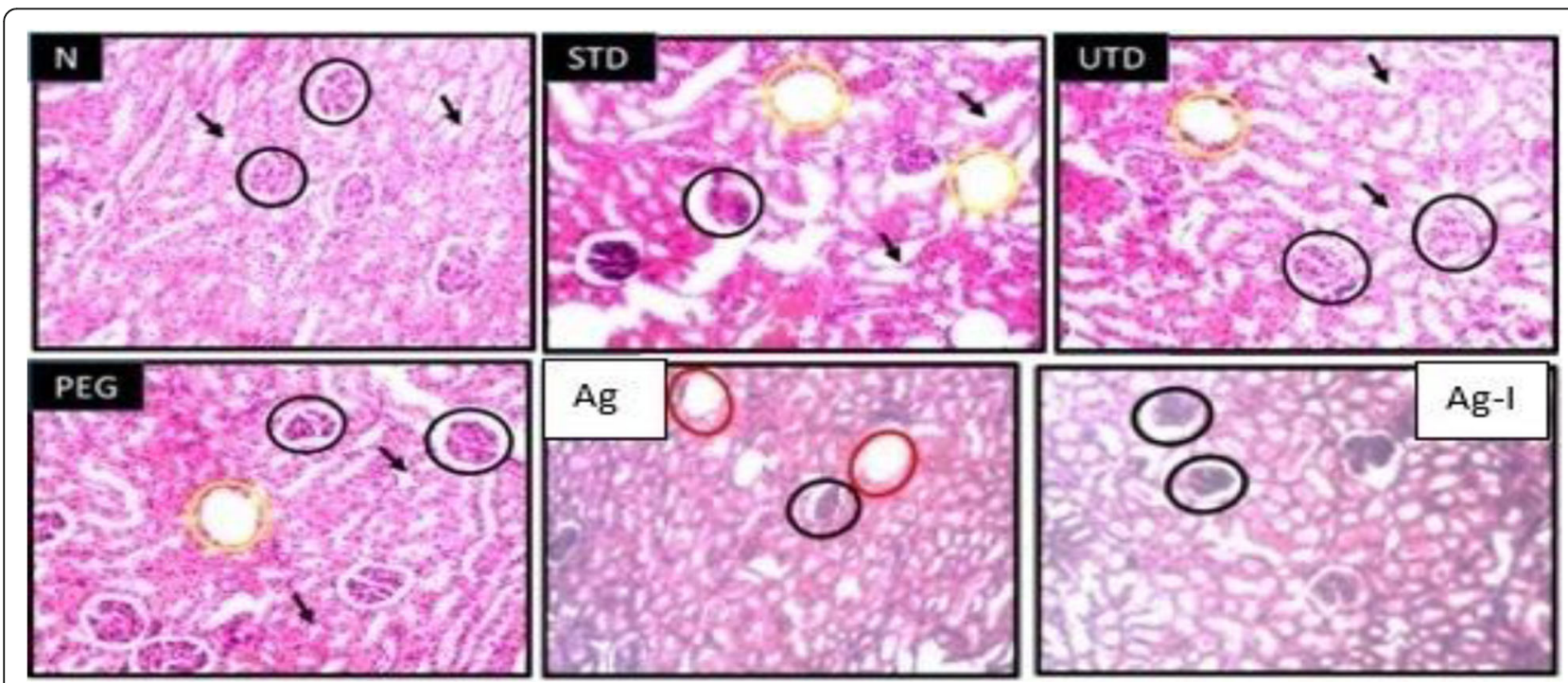

Fig. 2 Effect of PEG, Ag-NP and Ag-l NP treatment on histological sections of kidney in excision wound inflected albino rats. Hematoxylin and eosin stain at $\times 100$ and $\times 400$ magnification 
degeneration marked by the large halo-spaced bowman space (yellow and red circles) shows that Ag-I NP, preserved the integrity of the kidney cells.

\section{Conclusion}

Silver nanoparticles (Ag NPs) and iodine-doped silver nanoparticle (Ag-I NP) altered haematological parameters in the rats and also influenced some biochemical changes in the serum of the rats. While in the histopathological study, the antioxidant present in the plant extract used to synthesize Ag NPs and Ag I-NPs may have functioned in synergy to maintain and preserve the integrity of the hepatocytes and renal corpuscles of the rats.

\section{Availability of materials}

Not applicable.

\section{Authors' contributions}

OK Shittu: conceived, designed and supervised the study; OI Oluyomi: writing- original draft and performed the experimental procedures; TY Gara: writing- review and editing. All authors read and approved the final manuscript.

\section{Funding}

None.

\section{Declarations}

\section{Ethics approval and consent to participate}

The present study was approved by the Ethical Committee on the use of animals for research, Department of Biochemistry, Federal University Technology, Minna, Nigeria. Handling of the rats was in accordance with the standard principles of laboratory animal care of the United States National Institutes of Health (NIH, 1978).

\section{Consent for publication}

All authors consent to submission and publication of this manuscript.

\section{Competing interests}

The authors declare that they have no competing interests.

\section{Author details}

${ }^{1}$ Biochemistry Department, School of Life Sciences, Federal University of Technology, P.M.B 65, Minna, Niger State, Nigeria. ${ }^{2}$ Nanotechnology research Group, Centre for Genetic Engineering and Biotechnology, Federal University of Technology, P.M.B 65, Minna, Niger State, Nigeria. ${ }^{3}$ Africa Centre of Excellence for Mycotoxin and Food Safety, Federal University of Technology, P.M.B 65, Minna, Niger State, Nigeria.

Received: 26 May 2021 Accepted: 13 September 2021

Published online: 23 September 2021

\section{References}

1. Van Koppen CJ, Hartmann RW. Advances in the treatment of chronic wounds: a patent review. Exp Opin Ther Patents. 2015;25(8):931-7.

2. Turns M. Prevention and management of diabetic foot ulcers. Brit J Commmun Nurs. 2015:S34-7.

3. Eming SA, Martin P, Tomic-Canic M. Wound repair and regeneration: mechanism, signaling and translation. Sci Transl Med. 2014;3(6):265.

4. Irwansyah I, Li YQ, Shi W, Qi D, Leow WR, Tang MB, et al. Gram-positive antimicrobial activity of amino acid-based hydrogels. Adv Mater. 2015;27(4): 648-54.

5. Li N, Luo HC, Yang C, Deng JJ, Ren M, Xie XY, et al. Cationic star-shaped polymer as an siRNA carrier for reducing MMP-9 expression in skin fibroblast cells and promoting wound healing in diabetic rats. Int J Nanomedicine. 2014;9:3377-87.
6. Church D, Elsayed S, Reid O, Winston B, Lindsay R. Burn wound infections. Clin Microbiol Rev. 2006;19(2):403-34

7. Jaspers L, Colpani V, Chaker L, Sven J, Muka T, Imo D, et al. The global impact of non-communicable diseases on householdsand impoverishment: a systematic review. Eur J Epidemiol. 2015;30:163-88.

8. Lebert C, Hutternlocher A. Inflammation and wound repair. Semin Immunol. 2014;26(4):315-20

9. Adamson R. Role of macrophages in normal wound healing: an overview. J Wound Care. 2009;18(8):349-51.

10. Abraham GE. The history of iodine in medicine part 1: from discovery to essentiality. Orig Intern. 2006;13(1):29-36.

11. Viswanathan $\mathrm{K}$, Babu DB, Jayakumar G, Raj GD. Anti-microbial and skin wound dressing application of molecular iodine nanoparticles. Mater Res Express. 2017;4(10):4003.

12. Jae Y, Hyeon-Kyeong S, Beom SK. Biological synthesis of gold nanoparticles using Magnolia kobus and diopyros kaki leaf extracts. Process Biochem. 2009, 44:1133-8.

13. Shittu OK, Stephen DI, Kure AH. Functionalization of biosynthesized gold nanoparticle from aqueous leaf extract of Catharanthus roseus for antibacterial studies. Afr J Biomed Res. 2017;20:195-202.

14. Echo IA, Osuagwu AN, Agbor RB, Okpako EC, Ekanem BE. Hepatotoxicity of methanol seed extract of Aframomum melegueta [Roscoe] K. Schum. (Grains of paradise) in Spraque-Dawley rats. World J. Appl Environ Chem. 2012;2:17-21.

15. Iwu MM. Handbook of African medicinal plants. Boca Raton: CRC Press; 1993. p. 219-21.

16. Okoye El, Ebeledike AO. Phytochemical constituents of Piper guineense (uziza) and their health implications on some microorganisms. Global Sci Res J. 2013:2(2):42-6.

17. Viswanathan K, Monisha P, Srinivasan M, Swathi D, Raman M, Dhinakar RG. Chlorhexidine-calcium phosphate nanoparticles polymer mixer based wound healing cream and their applications. Mater Sci Eng C. 2016;67:516-21.

18. Yakubu MT, Bilbis LS, Lawal M, Akanji M. Effect of repeated administration of sildenafil citrate on selected enzyme activities of liver and kidney of male albino rats. Nigerian J Pure Appl Sci. 2003:18:1395-400.

19. Dacie JV, Lewis SM. Practical Haematology. 7th ed. London: Churchill Livingstone: 1991. p. 521-34.

20. Misra HP, Fridovich I. The role of superoxide anion in the autoxidation of epinephrine and a simple assay for superoxide dismutase. J Biol Chem. 1972;247(10):3170-5

21. Sinha AK. Colorimetric assay of catalase. Anal Biochem. 1972:47(2):389-94.

22. Rotruck JT, Pope AL, Ganther HE, Swanson AB, Hafeman DG, Hoekstra W. Selenium: biochemical role as a component of glutathione perioxidase. Science. 1973;179(4073):588-90.

23. Bassey OA, Lowry OH, Brock MJ. A method for the rapid determination of alkaline phosphates with five cubic Millimetres of serum. J Biol Chem. 1946; 164:321-5.

24. Wright PJ, Leatherwood PD, Plummer DT. Enzymes in rats: alkaline phosphatase. Enzymologia. 1972;42:317-27.

25. IFCC (International Federation of Clinical Chemistry). Physicochemical quantities and units in clinical chemistry. J Clin Chem Clin Biochem. 1980; 18:829-54.

26. Lowry OH, Rosebrough NJ, Farr AL, Randall RJ. Protein measurement with the Folinphenol reagent. J Biol Chem. 1951:193:265-7.

27. Odeghe OB, Uwakwe AA, Monago CC. Some biochemical and haematological studies on the methanolic extract of Anthocleista grandiflora stem bark. Int J Appl Sci Technol. 2012;2(5):58-65.

28. Okunlola DO, Olorunnisomo OA, Binuomote RT, Amuda AJ, Agboola AS, Omole OG. Heamatology and serum quality of red Sokoto goats fed baobab (Adansonia digitata L.) fruit meal supplement. J Nat Sci Res. 2015; 5(17):54-6.

29. Özkan C, Kaya A, Akgül Y. Normal values of haematological and some biochemical parameters in serum and urine of New Zealand white rabbits. World Rabbit Sci. 2012;20(4):253-9.

30. Peters SO, Gunn HH, Imumorin IG, Agaviezor BO, Ikeobi CON. Haematological studies on frizzled and naked neck genotypes of Nigerian native chickens. Trop Anim Health Prod. 2011:43(3):631-8.

31. Mishra N, Tandon VL. Haematological effects of aqueous extract of ornamental plants in male Swiss albino mice. Vet World. 2012:5(1):19.

32. Manisha C, Kumar JD, Sandeep T, Ali MA. Effect of aluminum on different parts of brainstem of old rats: haematological, biochemical and morphological study. Res J Pharm Sci. 2013;2(3):6-11. 
33. Wagener FA, Carels CE, Lundvig DM. Targeting the redox balance in inflammatory skin conditions. Int J Mol Sci. 2013;14:9126-67.

34. Sen CK, Roy S. Redox signals in wound healing. Biochim Biophys Acta. 1780; 2008:1348-61.

35. Bedard K, Krause KH. The NOX family of ROS-generating NADPH oxidases: physiology and pathophysiology. Physiol Rev. 2007:87:245-313.

36. Darr D, Fridovich I. Free radicals in cutaneous biology. J Investig Dermatol. 1994;102:671-5.

37. Silveira PC, Venancio M, Souza P, Victor E, de Souza Notoya F, et al. lontophoresis with gold nanoparticles improves mitochondrial activity and oxidative stress markers of burn wounds. Mater Sci Eng C. 2014;44:380-5.

38. Mordi JC, IChipi-Ifukor PC, Kweki GR, et al. Preliminary toxicology profile of Dennettia tripetala (pepper fruit) methanolic leaves extract. Clin Phytosci. 2021;7:61. https://doi.org/10.1186/s40816-021-00298-w.

39. Kurahashi T, Fujji J. Roles of Antioxidative enzymes in wound healing. J Dev Biol. 2015;3:57-70.

40. Shittu OK, Aaron SY, Oladuntoye MD, Lawal B. Diminazene aceturate modified nanocomposite for improved efficacy in acute trypanosome infection. J Acute Dis. 2018;7(1):36-42.

41. Yakubu MT, Musa IF. Liver and kidney functional indices of pregnant rats following the administration of the crude alkaloids from Senna alata (Linn. Roxb) leaves. Iran J Toxicol. 2012;6:615-25.

42. Adeyemi OT, Osilesi O, Adebawo OO, Onajobi FD, Oyedemi SO, Afolayan AJ Alkaline phosphatase (ALP), aspartate aminotransferase (AST) and alanine aminotransferase (ALT) activities in selected tissues of rats fed on processed Atlantic horse mackerel (Trachurus trachurus). Adv Biosci Biotechnol. 2015;6: 139-52.

43. Shittu OK, Lawal B, Haruna GM, Berinyuy EB, Yusuf AA, Ibrahim AM. Hepatocurative effects of methanol extract from Nigerian bee propolis in carbon tetrachloride (CCl4) intoxicated rat. Eur J Biotechnol Biosci. 2015a;3(7):1-4.

44. Lawal B, Shittu OK, Abubakar AN, Umar MB, Ibrahim AM, Haruna GM. Biochemical evaluation in Wister rats (Rattus novergicus) following chronic exposure of methanol leaf extract of Telfairia occcidentalis. J Pharm Biomed Sci. 2015;5(9):740-4.

45. Shittu OK, Musa F, Gbadamosi DF. Trypanocidal activity and heamatological changes in T. brucei infected rats treated with methanolic leaf extract of Thymus vulgaris. Int J Biol Pharm Res. 2013:5:109-14.

46. Maneewattanapinyo P, Banlunara W, Thammacharoen C, Ekgasit S, Kaewamatawong T. An evaluation of acute toxicity of colloidal silver nanoparticles. J Vet Med Sci. 2011;73(11):1417-23.

47. Bashir L, Shittu OK, Prince CO, Asmau AN, Aisha MI. Evaluation of antioxidant activity of giant African snail (Achachatina magi- Nata) haemolymph in $\mathrm{CCl}^{-}$induced hepatotoxicity in albino rats. Brit J Pharm Res. 2015:6(3):141-54.

48. Oluyomi SA, Ifeoluwa A. Biochemical evaluation of silver nanoparticles in Wistar rats. Int Scholarly Res Notice. 2014;196091:8. https://doi.org/10.1155/2 014/196091

49. Shittu OK, Elekwechi U, Musa BB, Lawal B. Antitrypanosomal activities and effect of ethyl acetate extract of honey bee (Apis Mellifera) on haematological parameters of Trypanosoma brucei brucei infected rats. J Appl Biol Biotechonol. 2015b;3(1):29-35.

50. Umbreit TH, Franke-Carroll S, Weaver $\mathrm{JL}$, et al. Tissue distribution and histopathological effects of titanium dioxide nanoparticles after intravenous or subcutaneous injection in mice. J Appl Toxicol. 2012;32:350-7.

51. Zhang Q, Hitchins VM, Scharand AM, Hussain SM, Goering PL. Uptake of gold nanoparticles in murine macrophage cells without cytotoxicity or production of pro-inflammatory mediators. Nanotoxicology. 2011;5:284-95.

\section{Publisher's Note}

Springer Nature remains neutral with regard to jurisdictional claims in published maps and institutional affiliations.

\section{Submit your manuscript to a SpringerOpen ${ }^{\circ}$ journal and benefit from:}

- Convenient online submission

- Rigorous peer review

- Open access: articles freely available online

- High visibility within the field

- Retaining the copyright to your article

Submit your next manuscript at $\boldsymbol{\nabla}$ springeropen.com 